\title{
Review of the carriage of zoonotic bacteria by arthropods, with special reference to Salmonella in mites, flies and litter beetles
}

\author{
A. D. Wales', J. J. Carrique-Mas', M. Rankin², B. Bell ${ }^{3}$, B. B Thind ${ }^{4}$, R. H. \\ Davies $^{1 *}$ \\ ${ }^{1}$ Department of Food and Environmental Safety and ${ }^{2}$ Scientific Services Unit, Veterinary Laboratories \\ Agency, Woodham Lane, New Haw, Addlestone, Surrey KT15 3NB, United Kingdom. \\ ${ }^{3}$ ADAS, Woodthorne, Wergs Road, Wolverhampton, WV6 8TQ, United Kingdom. \\ ${ }^{4}$ Central Science Laboratory, Sand Hutton, York . YO41 1LZ, United Kingdom.
}

*Author for correspondence:

Tel: $\quad+441932357361$

Fax: $\quad+441932357595$

Email: r.h.davies@vla.defra.gsi.gov.uk

\section{Impacts:}

- To review the evidence concerning farm arthropods in the transmission and maintenance of zoonotic bacteria

- To examine in detail evidence concerning flies, litter beetles and poultry mites in relation to Salmonella in commercial egg producing flocks

- To highlight the gaps in understanding, particularly of field situations

This is the peer reviewed version of the following article: Wales, A.D., Carrique-Mas, J.J., Rankin, M., Bell, B., Thind, B.B., Davies, R.H., 2010. Review of the carriage of zoonotic bacteria by arthropods, with special reference to Salmonella in mites, flies and litter beetles. Zoonoses Public Health 57, 299-314., which has been published in final form at http://dx.doi.org/10.1111/j.1863-2378.2008.01222.x This article may be used for non-commercial purposes in accordance with Wiley Terms and Conditions for Self-Archiving.

\section{Key words:}

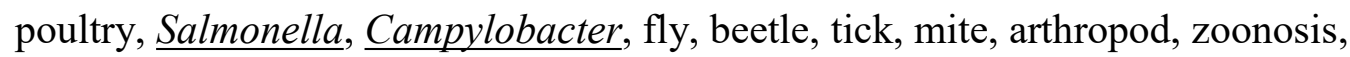
review

\section{Running title:}

Carriage of zoonotic bacteria by arthropods 


\section{Summary}

This systematic review considers the relationship between arthropods commonly found on and around livestock premises, and zoonotic bacteria. The principal focus is upon insects and arachnids on poultry units, where houses, litter and manure provide good conditions for the growth, multiplication and protection of flies, beetles and mites, and where zoonotic pathogens such as Salmonella and Campylobacter are prevalent. Other members of the Enterobacteriaceae and the taxa Clostridium, Helicobacter, Erysipelas and Chlamydiaceae are also discussed. Salmonella is widely distributed in the flies of affected livestock units, and is detectable to a lesser degree in beetles and mites. Persistent carriage appears to be common and there is some field and experimental evidence to support arthropod-mediated transmission between poultry flocks, particularly carry-over from one flock to the next. Campylobacter may readily be isolated from arthropods in contact with affected poultry flocks, although carriage is short-lived. There appears to be a role for flies, at least, in the breaching of biosecurity around Campylobacter-negative flocks. The carriage of other zoonotic bacteria by arthropods has been documented, but the duration and significance of such associations remain uncertain in the context of livestock production. 


\section{Introduction}

The occurrence and persistence of zoonotic agents on livestock farms has long been of concern, due to the likelihood of some of these evading hygiene barriers, or colonising processing plant, and contaminating human food. Products such as table eggs, which undergo minimal processing and which may frequently be consumed uncooked or poorly-cooked, have been a particular focus of concern in relation to Salmonella (Hogue et al., 1997; Palmer et al., 2000). Under European Union Zoonoses Regulation 2160/2003, Member States are required to put into place control plans for the reduction of specified zoonotic agents at farm level. One provision (Regulation 1237/2007) is for the mandatory heat treatment of eggs from layer flocks that are positive for Salmonella serovars Enteritidis or Typhimurium from the start of 2009, which will gravely affect the economic viability of such flocks.

Arthropods occur universally on livestock units and typically are numerous around laying flocks, due to layer housing offering many suitable niches all year round, including persistent faecal substrates, insulation and accumulated dust as well as long production cycles with infrequent thorough cleaning. It has often been suspected that arthropods may be involved in the epidemiology of zoonotic agents on farms, as has already been established for Salmonella Enteritidis and rodent pests in layer houses (Guard-Petter, 2001; Garber et al., 2003; Liebana et al., 2003). With the increasing application of mandatory controls upon zoonoses at farm level, it is becoming more important that the role of farm arthropods in the maintenance and spread of undesirable micro-organisms is well understood. Such insights may indicate suitable avenues for effective controls on zoonoses, or alternatively they may indicate where arthropod-mediated transmission could frustrate alternative attempts at control.

Within the phylum Arthropoda, the most significant taxa for animal production are the classes Insecta and Arachnida. Amongst insects, adult and larval forms of flies and beetles have been the principal focus of farm zoonosis investigations, whilst mites and ticks represent the arachnids of primary concern. Arthropods potentially have roles in zoonotic disease relating to the maintenance on-farm of zoonotic agents, horizontal inter- or intra-species transmission of such agents on or around farms, and the direct transfer of zoonotic agents from farms to human populations. In addition, certain arthropod infestations can cause debility among stock thus lowering resistance to zoonotic agents, for example in the case of red mite causing anaemia in chickens (Chauve, 1998).

The present review attempts to draw together what is known in this field, with a particular emphasis on the pressing issues of Salmonella and commercial layer flocks. A systematic review of the relevant arthropod groups is followed by consideration of the principal bacterial zoonoses of farm animals for which evidence of arthropod carriage exists. Finally, there is a brief discussion of some miscellaneous pathogens of potential significance. Where sufficient information exists to describe an arthropod as a mechanical vector (carrier) or a biological vector (permitting micro-organism multiplication or lifecycle stages), such a description is given. However, in a great many cases the data do not allow such distinctions to be made. Questions about whether certain arthropods may be reservoir hosts, maintaining particular zoonoses within their populations indefinitely (Ashford, 2003), are usually a matter of speculation based upon inferences from studies on persistence in individuals and not from longitudinal studies of populations. 


\section{Arthropod groups}

\section{Flies}

The flies (order Diptera) that are commonly reported around poultry enterprises in temperate and tropical climates are members of the families Muscidae, Fanniidae (small houseflies, Fannia species, sometimes classified within Muscidae) and Calliphoridae (blowflies), although the preponderance of the latter two families varies markedly between locations (Anderson and Poorbaugh, 1964; Conway, 1973; Hinkle and Hickle, 1999; Mian et al., 2002; Hald et al., 2004; Monteiro and do Prado, 2006). Layer houses are the principal foci of fly nuisance and investigations, due to the accumulation on-site of poultry manure for extended periods. The common housefly Musca domestica L. is the most heavily prevalent of all poultry unit flies, although other commonly-reported (but not necessarily numerous) Muscidae include the stable fly Stomoxys calcitrans L., the false stable fly Muscina stabulans (Fallén) and members of the genus $\underline{\text { Hydrotaea }}$ (= Ophyra) (Conway, 1973; Farkas and Papp, 1989; Mian et al., 2002). Hydrotaea aenescens (Wiedemann), the black dump fly, is found in association with layer houses in its native America (Nolan and Kissam, 1987; Olsen and Hammack, 2000) and has also become established in parts of Western Europe (Hogsette and Jacobs, 2003; Wittenberg et al., 2005) following its commercial use to control house flies on animal production units. Fruit flies (family Drosophilidae) and dung flies (family Sphaeroceridae) can also reach high numbers around poultry manure worldwide (Green, 1982; Farkas and Papp, 1989; Harrington and Axtell, 1994; Fernandes et al., 1995; Geden et al., 2001). The soldier fly Hermetia illucens (L.) (family Stratiomyidae) is a poultry house pest primarily in tropical and subtropical America (Geden et al., 2001), but it appears to be expanding its range, possibly due to climate change (Turchetto and Vanin, 2004).

$\underline{M}$. domestica is the fly most frequently associated with zoonoses worldwide, and its potential for spreading disease is shown by culture of human pathogens from trapped specimens: Salmonella and Shigella in the Middle East (Bidawid et al., 1978) and in Africa (Barro et al., 2006), and genera including Escherichia, Klebsiella, Enterobacter and Aeromonas in Asia (Sulaiman et al., 2000). A range of fly species was found to be naturally carrying zoonotic bacteria, including $E$. coli pathotypes, which could be recovered by culture from surface contact from live flies (Foerster et al., 2007). Whereas mere carriage of pathogens does not establish a vector role for any insect, intensive control of flies, principally $M$. domestica, proved protective for diarrhoea, shigellosis and seroconversion to enterotoxigenic E. coli amongst Israeli soldiers in the field (Cohen et al., 1991). M. domestica performs wide diurnal excursions around poultry houses (Anderson and Poorbaugh, 1964), and both M. domestica and Fannia species can be a nuisance to human settlements within a few miles of layer farms (Hinkle and Hickle, 1999; Mian et al., 2002; Winpisinger et al., 2005).

The significance of larval forms of flies for zoonoses is uncertain, but housefly larvae may occur within broiler and turkey litter (Rueda and Axtell, 1997) and are common in layer house manure (Hinkle and Hickle, 1999). Yersinia pseudotuberculosis and Ochrobactrum anthropi, both potentially zoonotic bacteria, have been cultured from the intestinal tracts of housefly larvae of turkey litter (Zurek et al., 2000). E. coli can sometimes survive pupation in house and stable flies (Rochon et al., 2005) but emergent houseflies typically have a sterile gut (Nazni et al., 2005). 


\section{Beetles}

Prominent among the beetle (order Coleoptera) pests of caged and litter-based poultry units are the scavenging lesser mealworm or darkling beetle Alphitobius diaperinus (Panzer) and two species in the genus Dermestes: the hide beetle D. maculatus DeGeer and the larder beetle D. lardarius L. (Pfeiffer and Axtell, 1980; Green, 1982; Armitage, 1986; Turner, 1986; Rueda and Axtell, 1997; Hinkle and Hickle, 1999; Geden et al., 2001; Skov et al., 2004; Kaufman et al., 2005). A. diaperinus adults have been shown, by direct culture, by transmission experiments and by serology of chicks inoculated with beetle homogenate, to carry a wide variety of bacterial, viral and coccidial organisms, many of them pathogens (Despins et al., 1994; Goodwin and Waltman, 1996; Crippen and Sheffield, 2006), and may readily survive cleaning and disinfection (C\&D) and insecticide treatments by retreating to inaccessible poultry house structures such as wall cavities (Skov et al., 2004). A. diaperinus and Dermestes species are destructive of poultry houses, boring into structural and insulating materials (Hinkle and Hickle, 1999; Geden et al., 2001). Other commonly-reported beetles include the predatory histerid beetle Carcinops pumilio (Erichson), providing a natural check on fly numbers, and the hairy fungus beetle Typhaea stercorea (L.) (Green, 1982; Rueda and Axtell, 1997; Skov et al., 2004). A systematic statewide survey in the eastern USA revealed in excess of 100 Coleoptera species in poultry manure (Pfeiffer and Axtell, 1980), and two deep pit layer houses investigated in the UK yielded 28 beetle species (Green, 1982). Ground beetles (Amara aulica [Panzer]) were found to be long-term residents of a depopulated British free-range poultry unit (Davies and Breslin, 2003b).

\section{Other insect groups}

Certain other taxa of poultry insect pests with a winged life stage can transmit diseases (Ruff, 1999), including the haemosporidian parasites causing avian malaria (Urquhart et al., 1987a). These groups include the families Simuliidae (blackflies), Culicidae (mosquitoes) and Hippoboscidae, and the genus Culicoides (midges). However, evidence for associations between these insects and bacterial zoonoses is lacking. Cockroaches (sub-order Blattodea) will opportunistically colonise many environments including poultry farms, and their carriage of human pathogens (Bennett, 1993; Fathpour et al., 2003; Tatfeng et al., 2005) makes them of interest in the context of poultry and zoonoses.

Fleas (order Siphonaptera), chewing lice (order Mallophaga) and true bugs (order Hemiptera) are insects regularly associated with poultry but currently of uncertain significance in the transmission of zoonotic agents. Chewing lice are recognised as insect parasites of free-living and caged poultry (De Vaney et al., 1980; Curtis and Boachie, 1982; de Chirinos et al., 2001). The internal microflora of avian lice appears to reflect that of the host skin (Lonc and Zlotorzycka, 1984). Lice may have a role in the transmission of chlamydial organisms among birds (Eddie et al., 1962). Fleas of poultry, including the sticktight and hen fleas (Echidnophaga gallinacea [Westwood] and Ceratophyllus gallinae [Schrank] respectively), share avian and mammalian hosts (Ruff, 1999). Fleas are vectors of certain animal viruses (Lockley, 1954; Gustafson et al., 1997) and can harbour zoonotic bacteria following experimental parenteral introduction (Vashchenok, 1980) but there is at present no evidence of a vector role for poultry zoonoses. True (or blood-sucking) bugs, and particularly the bedbug Cimex lectularius L., can infest poultry houses and cause severe clinical effects 
(Dulceanu et al., 1975; Monov and Topalski, 1980; De Vaney, 1986). Carriage of zoonotic agents ( $\underline{\text { Salmonella }}$ and $\underline{E \text {. coli }}$ ) by field specimens has been detected by culture, and multiplication of these agents in vivo has been recorded experimentally (Glukhov et al., 1982).

\section{Mites}

At least 2500 species of mites (class Arachnida), from 40 families, are closely associated with birds (Proctor and Owens, 2000). These mites can be divided into those that dwell primarily in or near the nest and those that reside mainly on the body of the host. The same authors also reported that the relationship between mites and birds is diverse: while some are benign others are extremely detrimental.

The most serious mite pests of poultry are the poultry red mite (Dermanyssus gallinae [De Geer]), the northern fowl mite (Ornithonyssus sylviarum [Canestrini and Fanzago]) and its equatorial equivalent the tropical fowl mite (Ornithonyssus bursa [Berlese]) (Ruff, 1999). These are haematophagous mites belonging to the order Mesostigmata. The poultry red mite is considered to be the most important cosmopolitan ectoparasite of poultry, with an extensive list of other avian as well as mammalian hosts including man. It is widespread geographically (Chauve, 1998), although not common in the USA where the northern fowl mite is considered to be more significant (Axtell and Arends, 1990; Hinkle and Hickle, 1999; Ruff, 1999). D. gallinae causes substantial morbidity in layer houses, where typically it becomes endemic and is difficult to control due to the mite's relatively short life cycle, its potential for exponential population growth and its prolonged survival of up to 34 weeks (Axtell and Arends, 1990) in niches in the fabric of the premises, even when starved. There is now good experimental evidence (discussed below in the 'Salmonella' section) that poultry red mite can acquire and transmit Salmonella from and to poultry. Control of the mite is made more difficult by a lack of age-related immunity in birds, probable widespread resistance to many available acaricides, and regulations which prevent the application of chemical insecticides to birds during lay (Chauve, 1998; Fiddes et al., 2005; Thind and Ford, 2007). O. sylviarum and O. bursa are usually introduced by wild birds or rodents. Poultry show an age-related immunity that reduces the impact of these two mite species, which also show limited survival times, of around 10 days, away from their hosts (Urquhart et al., 1987c; Axtell and Arends, 1990). Nonetheless, they are a significant pest, causing debility and sometimes significant mortality (Hinkle and Hickle, 1999).

There are also numerous non-haematophagous mite species associated with poultry houses. They are often small-bodied, have a relatively short lifecycle and a welldeveloped ability to select the most suitable habitats and environmental conditions (Danks, 2006). These mites belong to the orders Astigmata, Prostigmata and Mesostigmata and are composed of both predatory and non-predatory mites (Brady, 1970b; Hughes, 1976; Rueda and Axtell, 1997). Based on their habitats, these mites can be roughly divided into two main groups: (i) chicken manure and litter inhabiting mites, and (ii) feed pests and those found in dust and debris in proximity to cages.

For mites on poultry manure and litter, there is a considerable literature (Kennedy and Connell, 1969; Brady, 1970b; Hughes, 1976; Axtell and Arends, 1990; Rueda and Axtell, 1997), and it is possible that they are the numerically dominant taxon among arthropods in manure. Brady (1970b) surveyed about 50 farms in England and Wales, revealing at least 67 species of mites in poultry litter and manure. Extremely heavy infestations of Sancassania $(=$ Caloglyphus $)$ berlesei (Michael) were noted in a 
number of English poultry farms, along with predatory mites belonging to the family Cheyletidae (B. B. Thind, unpublished data). Cheletid mites have also been reported in poultry litter by other workers (Brady, 1970b; Rueda and Axtell, 1997); they mostly feed on active juvenile stages of astigmatid mites and provide an indication of heavy mite infestation. There are, in addition, many predatory mites found in poultry manure that may provide beneficial fly control (Green, 1982), for example the macrochelid mites (Mesostigmata). The most commonly encountered marochelids are Macrocheles muscaedomesticae (Scopoli) and Glyptholaspis confusa Foa. Another species, Macrocheles glaber (Müller), is also found occasionally on manure, and all three species are predators of the eggs and immature stages of Diptera and other insects. Androlaelaps casalis casalis (Berlese), a generalist predator also found on poultry manure, has been reported to affect the behaviour of birds and possibly to cause irritation to workers (Kennedy and Connell, 1969).

In respect of mites in feed, it is well established that storage mites occur often in very large numbers in a large variety of cereal-derived feeds for animals including chickens (Williams, 1960; Freeman, 1979; Wilkin and Thind, 1984; Thind, 2000). The most common storage mites found in poultry houses are Acarus and Tyrophagus spp (Astigmata) with Acarus siro L., and Acarus farris (Oudemans) being predominant. It is highly likely that these are introduced through infested feed. In a recent limited investigation, old feed samples collected from poultry farms were analysed using flotation techniques and the most heavily infested sample contained more than 24,000 storage mites per kilogramme (B. B. Thind, unpublished data). Six species of storage mites (A. siro, Thyreophagus entomophagus (Laboulbene), Tyrolichus casei (Oudmans), S. berlesei, Rhizoglyphus echinopus (Fumouze and Robin) and Dermatophagoides pteronyssinus (Trouessart) were recorded, but $\underline{A}$. siro was predominant. It is worth noting that $\underline{S \text {. berlesei }}$ is also often found on poultry manure.

Various haematophagous and non-haematophagous mites, classified by some in the superfamily Dermanyssoidea and including D. gallinae and Ornithonyssus species, have been shown to be vectors or carriers of the agents of diverse zoonoses such as Lyme disease, tularaemia, Q fever, togaviral equine encepalitides, trypanosomiasis and hantavirus haemorrhagic fever. In particular, poultry red mite has been described as a vector for several viral, bacterial and rickettsial poultry pathogens (Zeman et al., 1982; Chauve, 1998). The subject of vector roles for the Dermanyssoidea has been reviewed by Valiente Moro et al. (2005). After reviewing the available literature, Brady (1970a) concluded that a direct link between non-haematophagus, nonpredatory mites and infectious agents could not be established. However, he argued that these mites are exposed to the same viruses and bacteria as beetles, but mites may have a greater chance to acquire them because of their large numbers and from being so pervasive. It is therefore not unreasonable to speculate that mites that feed on both manure and feed could transfer viruses and bacteria to the feed.

\section{Ticks}

Soft ticks (family Argasidae), especially of the genus Argas, can cause significant morbidity and mortality among poultry flocks, especially in the tropics (Ruff, 1999). Argas persicus (Oken), the common poultry tick, is the most commonly encountered species in association with poultry and is found as far north as the southern USA, continental Europe, and occasionally in the UK (Urquhart et al., 1987b; Pavlovic and Nesic, 1991; Goddard, 2006). Adults and nymphs only visit host birds to feed, 
approximately every month, and adults will survive for months to years in the fabric of poultry houses away from birds (Srivastava et al., 1981; Urquhart et al., 1987b). Surveys in Pakistan have shown $8-24 \%$ of birds to be parasitised at any one time (Khan et al., 2001; Shah et al., 2006) with peak populations in summer (Oyoun et al., 1990; Shah et al., 2006). Deleterious effects on production and welfare in areas of high tick activity can be substantial (Urquhart et al., 1987b; Khan et al., 2001).

Argasid ticks will transmit avian bacterial, rickettsial and parasitic diseases (Ruff, 1999). They can also harbour West Nile virus, a zoonotic agent (Schmidt and Said, 1964; Mumcuoglu et al., 2005), and will transmit it to birds under experimental conditions (Abbassy et al., 1993). Avian-adapted Salmonella serotypes have been isolated from $\underline{A}$. persicus in field and experimental investigations (Stefanov et al., 1975; Gyurov, 1983) and several other Enterobacteriaceae have been cultured from field specimens of poultry-associated Argas species (Buriro, 1983; Montasser, 2005; Shah et al., 2006). However, a vector role for ticks in respect of Enterobacteriaceae, including Salmonella, remains speculative.

\section{Zoonotic agents}

\section{Salmonella}

Food-borne human salmonellosis typically manifests as gastroenteritis, although more severe septicaemic infections are also seen. It is closely associated with non-speciesadapted serovars, commonly Enteritidis and Typhimurium, and the principal source of these in developed countries is symptomless carriage by farmed species, particularly poultry (Velge et al., 2005).

Information on the distribution and persistence of Salmonella among farm arthropods centres principally on flies and litter beetles. It is well-established that $\underline{\text { Salmonella }}$ can be cultured from flies, principally $\underline{M}$. domestica but specifically also $H$. aenescens, in the vicinity of farms where livestock are infected, including poultry, dairy and pig units (Letellier et al., 1999; Olsen and Hammack, 2000; Barber et al., 2002; Mian et al., 2002; Davies and Breslin, 2003a; Skov et al., 2008). Heavy fly populations have been identified as a risk factor for Salmonella excretion by feedlot cattle in Australia (Vanselow et al., 2007). Although wildlife vectors may be responsible for the introduction of some salmonellae to farms, it appears that contamination predominantly passes in the opposite direction, with Salmonellapositive livestock units contaminating surrounding bird and insect populations (Skov et al., 2008). Insects may therefore play a vector role by direct transfer between production units, by transfer to insectivorous birds or, in the case of wider-ranging flies, by transfer to human environments.

It is evident that flies can transmit $\underline{S}$. Enteritidis between each other and to rodents (Ostrolenk and Welch, 1942). Salmonella Typhimurium has been transmitted experimentally to humans from dog faeces, via houseflies causing contamination of food (Greenberg, 1964). The persistence of $\underline{S}$. Typhimurium in flies has been the subject of investigations showing multiplication and carriage of the bacterium for up to 10 days, independent of initial dose, in the intestine of gnotobiotic houseflies (Greenberg et al., 1970). Non-gnotobiotic houseflies exposed to adult hens excreting $\underline{S}$. Enteritidis readily acquired the bacterium, both as body surface and intestinal contaminants, but onward transmission to Salmonella-negative hens could not be demonstrated except following oral gavage of Salmonella-colonised flies (Holt et al., 2007). In the same study, findings of a strong attachment of Salmonella cells to the fly 
body surface plus very low levels of Salmonella in the crop and salivary glands indicated that defaecation may pose the highest risk of Salmonella transmission from flies. It was suggested that the huge fly populations that may sometimes develop in commercial laying houses in hot weather may present a greater risk than the relatively small numbers of flies that were used in the transmission experiments.

$\underline{S}$. Typhimurium was less persistent in the sheep blowfly Lucilia (=Phaenicia) sericata (Meigen) (family Calliphoridae) and was suppressed strongly in gnotobiotic housefly adults and blowfly larvae by co-inoculation of the bacterium Proteus mirabilis (Greenberg et al., 1970). P. mirabilis is common in larval and adult fly environments, is a common housefly intestinal isolate, and appears to secrete an agent that causes rapid killing of a wide range of bacteria in acid conditions such as are found in the midgut of fly larvae (Greenberg and Klowden, 1972). Furthermore, P. mirabilis may be important in the elimination of bacteria during pupation, which is the usual fate of pathogens such as Salmonella in conventional, but not gnotobiotic, houseflies (Greenberg and Klowden, 1972). In addition to bacterial suppression of pathogens, some Calliphoridae are known to secrete intestinal agents that lyse bacteria found on decaying flesh (Crowley and Houck, 2002).

The question of whether Salmonella multiplies in or on houseflies in the field, thereby potentially allowing flies to act as biological vectors (as opposed to mechanical carriers), is unresolved. The evidence of a suppressive effect of the fly intestinal flora on Salmonella suggests that the bacterial multiplication observed in the gnotobiotic fly may not be seen in the field. However, the housefly mouthparts have been identified as a site of proliferation for E. coli (Kobayashi et al., 1999), and so an external site of multiplication may also exist for Salmonella. There is not enough evidence to regard flies as reservoir hosts for Salmonella, despite findings of fly to fly transmission.

In the field, investigations show that flies captured around Salmonella-positive poultry flocks regularly yield salmonellae, typically of the same serotypes and subtypes that are found in the flock (Olsen and Hammack, 2000; Davies and Breslin, 2003a; Kinde et al., 2005). Indeed, fly samples may be sensitive and early indicators of Salmonella flock infections (Bailey et al., 2001; Kinde et al., 2005) and can be the only samples among hundreds taken in layer house and hatchery investigations from which Salmonella is cultured (R. H. Davies, unpublished observations). High numbers of Salmonella organisms may be found in samples of flies when compared with other environmental samples from laying houses, when semi-quantitative cultural methods are used (Wales et al., 2006a, b). It is, however, still unclear whether flies significantly aid dissemination of Salmonella within and between flocks, and/or contribute to carry-over of the bacterium to subsequent flocks. Houseflies appear to move widely within and around poultry houses (Anderson and Poorbaugh, 1964), but Salmonella-negative layer flocks may fail to become infected despite heavily-infected flocks in adjacent buildings that are also infested with houseflies (R. H. Davies,

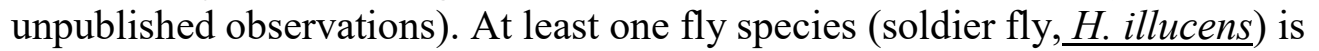
potentially of benefit with regard to Salmonella contamination, in respect of the ability of its larvae to effect a reduction of several $\log$ units in $\underline{S}$. Enteritidis numbers in poultry manure over a period of days (Erickson et al., 2004).

Experimental work with $\underline{A}$. diaperinus has shown that viable $\underline{S}$. Typhimurium can be recovered from lesser mealworm beetle carcases for at least 45 days following experimental ingestion (de las Casas et al., 1968). However, exposing adult beetles to levels of $\underline{S}$. Enteritidis more typical of heavily-contaminated feed, i.e. $10^{3}$ to $10^{4} \mathrm{cfu}^{-1}$, did not produce detectable persistent contamination (Davies and Wray, 
1995). Surveys of lesser mealworm adults from layer flock houses (Kinde et al., 2005) show a low proportion to be culture-positive for Salmonella after surface disinfection of the beetles. Studies with broilers have reported Salmonella isolations from adult beetles (Davila et al., 1996; Goodwin and Waltman, 1996; Skov et al., 2004), although even Salmonella-positive flocks do not necessarily yield positive beetles (Davies and Wray, 1995). The frequency of Salmonella isolates from individual or pooled beetles from Salmonella-positive flocks is low compared with similar samples of flies, even without surface disinfection procedures (Skov et al., 2004). Salmonella serovars and subtypes (determined using molecular genetic techniques) from beetles generally reflect those from associated flock and environmental sources (Liebana et al., 2003; Skov et al., 2004; Kinde et al., 2005), but not invariably (Olsen and Hammack, 2000).

A potential role for lesser mealworms in the carry-over of Salmonella between flocks has been suggested, but the evidence is conflicting. A Danish study concluded that the level of beetle infestation was not a risk factor for $\underline{S}$. Typhimurium contamination of broiler flocks (Skov et al., 1999), and in the UK survival by large numbers of litter beetles following C\&D between broiler flocks was not associated with carry-over of Salmonella infection (Davies et al., 2001). However, two longitudinal studies in Denmark of young broiler breeder flocks infected with various Salmonella serotypes showed that the elimination of Salmonella between sequential flocks was only achieved in concert with the elimination of $\underline{A}$. diaperinus (Baggesen et al., 1992; Brown et al., 1992). This may simply reflect enhanced C\&D causing the simultaneous elimination of both beetles and Salmonella. However, beetles carrying

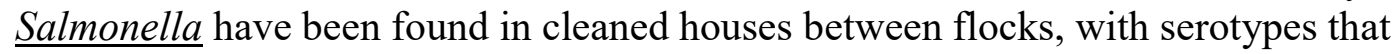
match those found in subsequent flocks, thus providing tentative evidence of a role in carry-over (Skov et al., 2004). Furthermore, large populations of $\underline{A \text {. diaperinus }}$ larvae increase the risk of carry-over of $\underline{S}$. Typhimurium and other $\underline{\text { Salmonella serotypes in }}$ turkey houses in the UK (R. H. Davies, unpublished observations). The long survival of Salmonella in dead $\underline{A}$. diaperinus provides a potential route for carry-over after $\mathrm{C} \& \mathrm{D}$ (de las Casas et al., 1968). There is no evidence for $\underline{A}$. diaperinus having roles as a biological vector or reservoir host in respect of Salmonella.

Dermestes spp. may occur commonly in wooden poultry houses but have been little studied in the context of zoonoses. The hide beetle ( $\underline{D}$. maculatus $)$ required high $\left(10^{7} \mathrm{cfu}\right)$ and repeated doses of Salmonella to establish intestinal carriage (Julseth et al., 1969), suggesting that this route may not be significant in its maintenance and dissemination. Nonetheless, the beetle's preference for feeding on poultry and rodent carcasses (Geden et al., 2001) may expose it to high levels of ingested Salmonella, and its tendency to bore and hide in poultry house structures will, like $\underline{A}$. diaperinus, allow it to escape C\&D and potentially to carry Salmonella externally or internally from one flock to the next. The histerid beetle $\underline{C}$. pumilio has been shown to acquire $\underline{S}$. Enteritidis and to carry and excrete viable organisms for up to two weeks following ingestion of contaminated fly eggs (Gray et al., 1999). Whilst C. pumilio might contribute to dissemination of Salmonella within a layer house, its role is potentially very limited as it is restricted to manure heaps throughout its life cycle (Geden and Stoffolano, 1988) and on balance its beneficial predatory effect on fly eggs (Green, $1982)$ may be more important. Ground beetles $(\underline{A \text {. aulica }})$ yielded $\underline{S}$. Enteritidis phagetype 4 isolates for at least 26 months on a depopulated poultry unit, but only in the context of persistent contamination elsewhere in the environment (Davies and Breslin, $2003 \mathrm{~b}$ ). Where $A$. diaperinus has been eliminated, other pests can flourish, and in one such case the hairy fungus beetle ( $\underline{\text { T stercorea }}$ ) become poorly-controlled on a broiler 
unit and specimens yielded isolates of Salmonella Infantis during and between flocks also infected with this serotype (Hald et al., 1998).

Cockroaches have been reported to carry Salmonella in poultry units in the Middle East (Fathpour et al., 2003) and in a hatchery and poultry feedmill in the USA (Kopanic et al., 1994). Cockroaches can transmit salmonellae, including $\underline{S}$. Typhimurium, to other cockroaches and to eggshells (Kopanic et al., 1994; Fathpour et al., 2003). The long-term (100 days plus) persistence of $\underline{S}$. Typhimurium in roach carcases (Klowden and Greenberg, 1976) mirrors that in lesser mealworm beetles. $\underline{S}$. Typhimurium excretion by American cockroaches (Periplaneta americana L.) was significantly extended by temporary or permanent suppression of the roach gut flora by antibiotic (Klowden and Greenberg, 1977). Indeed, in untreated cockroaches, multiplication of Salmonella was not observed, whereas in those with a suppressed gut flora, excreted numbers were clearly many multiples of the inoculum dose. This last observation indicates that the carriage and excretion of Salmonella by cockroaches, and perhaps by insects more widely, is affected by factors impacting the gut flora, which may include food source, season and life stage. Hosts may vary between being mechanical and biological vectors under the influence of such factors.

Bedbugs ( C. lectularis $)$ infesting poultry houses with endemic salmonellosis yielded isolates of various Salmonella serovars (including Typhimurium), albeit at a low prevalence. Experimentally, prolonged carriage and excretion of $\underline{S}$. Typhimurium and other serovars was observed following infected blood meals (Glukhov et al., 1982).

Among Acaridae, the poultry red mite $D$. gallinae has been shown experimentally to acquire $\underline{S}$. Enteritidis via feeding or cuticular contact and to carry it and permit bacterial multiplication for up to 14 days (Valiente Moro et al., 2007a), showing its potential to act as a biological vector. $\underline{S}$. Enteritidis-infected mites were capable of retransmitting the bacterium to blood in an in vitro mite feeding apparatus (Valiente Moro et al., 2007a), and caused persistent systemic and intestinal colonisation of birds when fed to day-old chicks (Valiente Moro et al., 2007c). Furthermore, natural carriage of Salmonella by red mites in layer houses of both Salmonella-positive and Salmonella-negative flocks has been demonstrated by polymerase chain-reaction (PCR) detection (Valiente Moro et al., 2007b), providing field evidence for the potential significance of red mite as a vector and reservoir host. The ubiquity of persistent red mite infestations, resistant to $C \& D$ regimes, in a high proportion of layer houses makes it of substantial interest in this respect. The avian-adapted

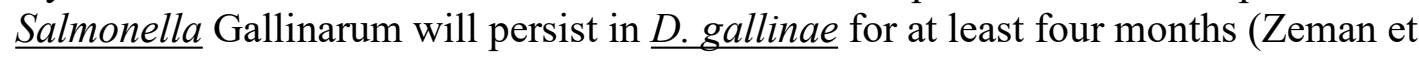
al., 1982).

In a laboratory investigation (B. B. Thind, unpublished data) a population of the manure- and feed-associated mite $\underline{S}$. berlesei was exposed to $\underline{S a l m o n e l l a}$ and released in a large enclosed arena. Viable Salmonella was detected after 24 hours on mites at a distance of over 10 metres from the point of release, indicating at least a potential mechanical vector role.

Ticks ( $\underline{\text { Argas persicus }}$ ) can carry culturable $\underline{S}$. Typhimurium naturally (Buriro, 1983), and experimentally they will harbour the serovar for many months and retransmit it to ducks by biting or when eaten (Glukhov, 1972). Field investigations have yielded isolates from ticks of the avian-adapted Salmonella biovars Gallinarum (Gyurov, 1983) and Pullorum (Stefanov et al., 1975), although ticks could not be clearly identified as vectors for bird infection in either case. 


\section{Other Enterobacteriaceae}

Escherichia coli, and particularly the zoonotic pathogen verocytotoxigenic E. coli (VTEC) O157:H7, has received particular attention in relation to farm arthropods, often as part of wider surveys of its distribution. VTEC O157:H7 is the most prominent member of a pathotype termed Enterohaemorrhagic E. coli. Human infection is associated with bloody diarrhoea and haemorrhagic colitis, plus lifethreatening extra-intestinal pathologies including haemolytic uraemic syndrome (Nataro and Kaper, 1998). Experimentally, houseflies appear to eliminate viable VTEC O157:H7 from their gut within three days, keeping the bacterium within an intestinal peritrophic membrane that may have a protective role for the insect (Kobayashi et al., 1999; Tellam et al., 1999). However, there is evidence that VTEC O157:H7 multiplies on housefly mouthparts and legs, and persists for at least four days in the fly's crop (Kobayashi et al., 1999; Sasaki et al., 2000), thus making it potentially a biological vector. The stable fly $(\underline{S \text {. calcitrans }})$ appears to have less ability than the housefly to prevent the internal multiplication and persistence of E. coli, which may reflect the former's food source (blood) which would expose it to comparatively little ingested $\underline{E}$. coli (Rochon et al., 2005).

Because cattle are considered to be the principal reservoir for VTEC O157:H7, most field investigations of arthropods and this pathogen have involved cattle units. Flies trapped on dairy and beef farms have yielded viable VTEC, VTEC O157 or

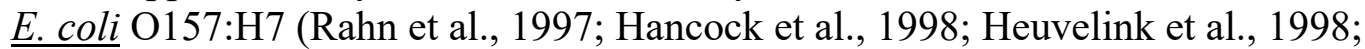
Shere et al., 1998). Where subtyping was performed, these fly isolates matched those from cattle. Experimentally, exposure of calves for two days to houseflies carrying E. coli $\mathrm{O} 157: \mathrm{H7}$ led to persistent colonisation of the calves by the bacterium and associated intermittent contamination of the drinking water (Ahmad et al., 2007). On turkey farms, houseflies and dump flies ( $\underline{H \text {. aenescens }})$ have been shown by PCR detection to be carrying $\underline{E}$. coli $\mathrm{O} 157: \mathrm{H} 7$ (Szalanski et al., 2004).

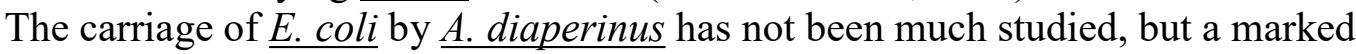
strain was transmitted to day-old chicks via larvae and adult beetles fed on the bacterium (McAllister et al., 1996). In the same study, contaminated mealworm larvae and adults excreted the strain for one and two weeks respectively after 24 hours of exposure in feed, a duration of excretion that suggests bacterial multiplication in or on the host.

E. coli ingested by Ornithodoros moubata, an argasid tick, appeared initially to multiply in the tick midgut but then to be phagocytosed and destroyed by the gut epithelium by 24 days post-ingestion (Matsuo et al., 2004). Mechanical carriage of E. coli for eight days by artificially-contaminated house dust mites has been reported (Santos, 2000).

Other Enterobacteriaceae considered to be potential farm zoonotic pathogens include the human enteropathogens Aeromonas caviae and Yersinia pseudotuberculosis. Houseflies have been shown experimentally to carry viable cells of both organisms and to transmit them onward to the environment (Zurek et al., 2001; Nayduch et al., 2002). Enterobacter cloacae and Klebsiella oxytoca similarly have potential human disease significance and have been found in association with a colony of lesser mealworm derived from a poultry house (Crippen and Sheffield, 2006); E. cloacae has also been cultured from the poultry tick $\underline{A}$. persicus (Montasser, 2005). Enterobacter sakazakii, an opportunistic human pathogen causing meningitis, enterocolitis and sepsis, will persistently colonise larval and adult stable flies, but only in the absence of a competing microflora in the fly's diet (Mramba et al., 2007). 


\section{Campylobacter}

Campylobacteriosis is a common zoonosis deriving particularly from the consumption of Campylobacter fetus subsp. jejuni in poultry meat. Broilers acquire the bacterium during rearing and are symptomless carriers. Human disease is characterised by diarrhoea and abdominal pain, although uncommon sequelae include extra-intestinal infections of a range of tissues and an immune-mediated demyelinating disorder, Guillain-Barré syndrome (Moore et al., 2005).

Experimentally inoculated houseflies will carry $\underline{C}$. jejuni for up to two days (Berndtson et al., 1991), and housefly-mediated transmission between chicks has been demonstrated (Shane et al., 1985). It has been theorised on the basis of epidemiological patterns, that fly contamination of hands, surfaces and cooked food may be significant in the occurrence of seasonal human campylobacteriosis, in addition to transmission through the poultry food chain (Nelson and Harris, 2006).

Field studies have shown a high prevalence of flies positive for Campylobacter by culture or PCR detection around poultry and pig units (Rosef and Kapperud, 1983; Gregory et al., 1997; Hald et al., 2004), including $\underline{S \text {. calcitrans }}$ and $\underline{H}$. aenescens (Szalanski et al., 2004). Where serotypes, biotypes and genetic subtypes of campylobacters have been examined, correlations have been found between poultry and fly isolates from the same units (Berndtson et al., 1996; Stern et al., 1997), and in one case adjacent sheep were found also to be carrying an indistinguishable strain (Hald et al., 2004). When flies associated with poultry flocks that are Campylobacternegative have been examined, they have been found also to be negative (Berndtson et al., 1996; Gregory et al., 1997). Observations that new flocks typically remain Campylobacter-negative for two to four weeks (Jacobs-Reitsma et al., 1995; Berndtson et al., 1996; Gregory et al., 1997) indicate that direct carry-over of campylobacters between sequential flocks by flies is unlikely, although not impossible as it may take some time before infection is detectable in a flock. A recent and substantial Danish study showed that comprehensive fly control, by means of wholehouse fly screens, was associated with highly significant protection of broiler flocks against Campylobacter infection, delaying the onset of infection in some flocks and providing absolute protection until slaughter in others (Hald et al., 2007). Therefore, breaches of biosecurity causing flock infection may often be mediated by flies, which may in turn have been contaminated by recent contact with faeces or contaminated water outside the poultry farm. This is consistent with the demonstrated short-term carriage and transmission of Campylobacter by flies, and their tendency for diurnal excursions (Anderson and Poorbaugh, 1964). The long-term maintenance of Campylobacter in fly populations in the absence of contaminated material is considered unlikely on the basis of present evidence.

The carriage of Campylobacter by lesser mealworms appears, as with flies, to be short-lived. $\underline{C}$. jejuni was isolated for up to three days from $\underline{A}$. diaperinus following experimental contamination in feed, and excretion of the bacterium by the larvae and its persistence in adult beetles was even briefer (Strother et al., 2005). Other investigators have reported similar findings and additionally have found that farmcontaminated beetles have become culture negative for Campylobacter by, at most, three days after removal from the farm (Templeton et al., 2006). Internal carriage of Campylobacter could not be demonstrated in a range of insects, including adult and larval lesser mealworms, following surface disinfection of specimens retrieved from a C. jejuni-contaminated broiler house (Jones et al., 1992), but the relative insensitivity of Campylobacter culture may have led to some false-negative results. 
Field studies tend to confirm the view that litter beetles do not constitute a reservoir for Campylobacter and are not likely to be significant in the carry-over of Campylobacter between flocks. Beetles obtained from houses after depopulation of Campylobacter-positive flocks (Skov et al., 2004) and before the introduction of flocks that subsequently became infected (Gregory et al., 1997) were found not to be contaminated with the bacterium. Campylobacter subtyping using serological and molecular genetic techniques indicates that broilers and $\underline{A}$. diaperinus share common Campylobacter strains within a flock (Aarts et al., 1995; Stern et al., 1997). However, these subtypes change between flocks and in none of 38 flocks examined were lesser mealworms found to be Campylobacter-positive before the organism was isolated from the corresponding broilers (Jacobs-Reitsma et al., 1995). The suspicion that in most cases campylobacters found on or in lesser mealworms simply reflect those in the current flock is strengthened by the observation that Campylobacter subtypes isolated from beetles tend to show a temporal lag behind the subtypes found in fresh poultry droppings (Bates et al., 2004), and differ from those found in adjacent poultry flocks and other livestock (Aarts et al., 1995). However, some degree of independent maintenance of the bacterium may occur in beetles and their immediate environment, as some divergence of subtypes between lesser mealworm beetles and associated poultry is seen on occasion (Aarts et al., 1995).

Heavy infestation of lesser mealworm beetles was shown, in a multivariate analysis, to be a significant risk factor for broiler flocks being Campylobacter-positive at the end of the rearing period, whereas various biosecurity practices were not found to be significant (Refregier-Petton et al., 2001). This raises the possibility, as with flies, that poorly-controlled litter beetles which achieve extremely high population densities may sometimes have a role as short-term vectors in the introduction of Campylobacter to a flock and possibly its dissemination among units on a farm. In addition, the presence of significant numbers of litter beetles is often associated with considerable structural damage to the chicken house, which may constitute a risk factor for infection in its own right.

There is a lack of any published associations between Campylobacter and members of the Arachnida. This may have more to do with the unimportance of acarid pests, notably mites, in the poultry sector affected by Campylobacter (i.e. broilers) than with a genuine absence of such associations.

\section{Other zoonoses of potential interest}

Among humans, Clostridium perfringens is associated with the common C. perfringens enterotoxin-mediated food poisoning, often traceable to poultry meat, and also with $\beta$ toxin-associated necrotic enteritis and myonecrosis (gas gangrene) (Rood and Cole, 1991; van Immerseel, 2004). C. perfringens has been isolated frequently from insect (fly and beetle) samples taken from infected broiler flocks (Craven et al., 2001). However the significance of this beyond being an indicator of flock status, given that infection of chicks appears to occur around hatching, is uncertain.

Helicobacter pylori colonises the human stomach mucosa and infection can lead to chronic gastritis, peptic and duodenal ulcer disease and gastric cancer (Ernst and Gold, 2000). H. pylori was detected frequently by PCR examination of houseflies trapped around dairy, poultry and pig units (Shineng and Stutzenberger, 2000). Although the persistence of $\underline{H}$. pylori DNA in captive flies was demonstrated, the 
existence of viable organisms was not confirmed and a source of the bacterium was not found in the associated farms.

The poultry red mite ( $\underline{\text { D. gallinae }})$ has yielded isolates of Erysipelothrix rhusiopathiae, a poultry pathogen and potentially zoonotic bacterium, in the context of clinical hen erysipelas (Chirico et al., 2003). Human E. rhusiopathiae infection is associated with occupational exposure to animals and animal products, and usually manifests as skin lesions (erysipeloid), although, uncommonly, systemic disease is seen (Reboli and Farrar, 1989).

Chlamydia sp. were reportedly isolated by mouse passage from pools of mites (Glycyphagus, Cheyletus and mesostigmatid species) from turkey accommodation and from shaft lice (Menopon gallinae) taken from chickens (Eddie et al., 1962).

Chlamydiophila psittaci (formerly Chlamydia psittaci) causes flu-like symptoms and often severe respiratory disease in humans and has been involved in zoonotic outbreaks associated with chlamydiosis in turkey and duck flocks (Longbottom and Coulter, 2003).

\section{Conclusions}

The zoonotic enteropathogens of primary interest in this context are Salmonella and Campylobacter. Flies, more so than litter beetles, appear to provide a sensitive and

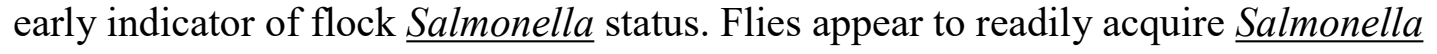
from excreting hens and may act as vectors (probably mechanical but potentially biological), contributing to enhanced dissemination of Salmonella within and between flocks, and to nearby human settlements, although direct evidence of these roles in the field is lacking and there is some evidence to the contrary. The important mode(s) of Salmonella carriage by flies remain unclear: fly faeces potentially carries the heaviest Salmonella load, but microbial suppression of ingested Salmonella may mean that the predominant mode of transmission is on external structures of the fly. A number of

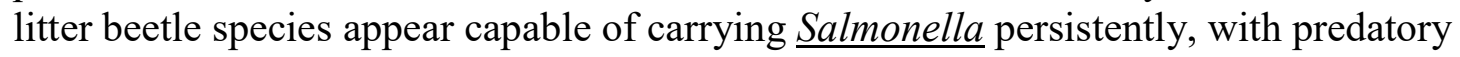
species potentially acquiring it from contaminated fly eggs or larvae, and there is indirect evidence that beetles can contribute to carry-over of the bacterium from one flock to the next. This may particularly apply if large populations of beetles can survive disinfection and insecticide treatment by remaining in the insulation layer of poultry houses in which the level of Salmonella contamination before depopulation was high and the time between flocks is short.

The poultry red mite can harbour $\underline{S}$. Enteritidis and $\underline{S}$. Gallinarum, and can retransmit Salmonella when ingested by young chicks. Its role in the maintenance and transmission of salmonellae other than $\underline{S}$. Gallinarum amongst adult layers is still unclear. Bedbugs, a potential pest in layer and breeder houses, can acquire and carry $\underline{\text { Salmonella }}$, but roles in maintenance and carry-over have not been investigated. A host of other mites are found in manure, litter, dust and feed, and it is reasonable to suppose that they will be exposed to and carry Salmonella. Evidence for a role in Salmonella ecology is currently lacking, but mites that move between contaminated substrates and feedstuffs, such as $\underline{S}$. berlesei, may have the greatest potential significance. Certain ticks ( $\underline{\text { A. persicus }}$ ) have been identified as carriers of avian Salmonella strains, and experimentally as persistent vectors of the zoonotic serovar $\underline{S}$. Typhimurium. The significance of these observations where ticks occur in the context of outbreak or endemic poultry infections is uncertain.

Carriage of Campylobacter by flies and beetles appears to be more short-lived than for Salmonella, probably reflecting the former's comparative fragility outside of its 
mammalian hosts, and an arthropod role in the carry-over of Campylobacter between flocks seems unlikely. Nonetheless, flies and litter beetles do carry flock-associated Campylobacter strains and, with flock infections apparently consequent upon biosecurity breaches during the middle period of broiler rearing, there is scope for arthropods to act as short-term vectors in this process. There is now good evidence for this in relation to flies, and risk analysis has provided a pointer in this direction for litter beetles.

There is a variety of other potential zoonotic enteropathogens ( $\underline{\text { E. coli }}$, Klebsiella Aeromonas, Yersinia, Enterobacter, C. perfringens, $\underline{H}$. pylori $)$ for which insect (mostly fly) carriage has been observed. The significance of these observations is currently unknown, but few of these pathogens appear currently to have close epidemiological links with poultry production.

The drive towards monitoring and control of foodborne zoonoses (particularly Salmonella) on farms, whether by legislative means or voluntary assurance schemes, requires that all significant contributors to the introduction and persistence of such infectious agents be understood. For arthropods, there is a reasonable body of experimental evidence pointing to a potential role as vectors for Salmonella (including the important serovars Enteritidis and Typhimurium) and Campylobacter. However, for the most part, conclusive field evidence for the significance of arthropods is either lacking or conflicting, as might be expected for such a multifactorial phenomenon as zoonotic agent ecology on farms. For poultry, it is likely that any real or potential risk may rise with increasing levels of zoonotic bacteria excreted by poultry, with very high levels of potential arthropod vectors and with close associations, either spatial or temporal, between flocks. Such factors require further detailed longitudinal studies using sensitive detection methods and frequent intensive sampling, starting before the onset of flock infection.

\section{List of abbreviations}

C\&D: Cleaning and disinfection

PCR: Polymerase chain reaction

VTEC: Verocytotoxigenic E. coli

\section{Acknowledgement}

This review was commissioned and funded by Defra project OZ0325 


\section{References}

Aarts, H. J. M., L. Vanlith and W. F. Jacobs-Reitsma, 1995: Discrepancy between Penner serotyping and polymerase chain-reaction fingerprinting of Campylobacter isolated from poultry and other animal sources. Lett. Appl. Microbiol. 20, 371-374.

Abbassy, M. M., M. Osman and A. S. Marzouk, 1993: West Nile virus (Flaviviridae: Flavivirus) in experimentally infected Argas ticks (Acari: Argasidae). Am. J. Trop. Med. Hyg. 48, 726-737.

Ahmad, A., T. G. Nagaraja and L. Zurek, 2007: Transmission of Escherichia coli O157:H7 to cattle by house flies. Prev. Vet. Med. 80, 74-81.

Anderson, J. R. and J. H. Poorbaugh, 1964: Observations on the ethology and ecology of various Diptera associated with Northern California poultry ranches. J. Med. Entomol. 1, 131-147.

Armitage, D. M., 1986: Population changes of four species of insects (Col. \& Dipt.) in three deep pit poultry houses. Entomologist's Monthly Magazine 122, 75-77.

Ashford, R. W., 2003: When is a reservoir not a reservoir? Emerg. Infect. Dis. 9, 1495-1496.

Axtell, R. C. and J. J. Arends, 1990: Ecology and management of arthropod pests of poultry. Annu. Rev. Entomol. 35, 101-126.

Baggesen, D. L., J. E. Olsen and M. Bisgaard, 1992: Plasmid profiles and phage types of Salmonella typhimurium isolated from successive flocks of chickens on three parent stock farms. Avian Pathol. 21, 569-579.

Bailey, J. S., N. J. Stern, P. Fedorka-Cray, S. E. Craven, N. A. Cox, D. E. Cosby, S. Ladely and M. T. Musgrove, 2001: Sources and movement of Salmonella through integrated poultry operations: A multistate epidemiological investigation. J. Food Prot. 64, 1690-1697.

Barber, D. A., P. B. Bahnson, R. Isaacson, C. J. Jones and R. M. Weigel, 2002: Distribution of Salmonella in swine production ecosystems. J. Food Prot. 65, 1861-1868.

Barro, N., S. Aly, O. C. A. Tidiane and T. A. Sababenedjo, 2006: Carriage of bacteria by proboscises, legs, and feces of two species of flies in street food vending sites in Ouagadougou, Burkina Faso. J. Food Prot. 69, 2007-2010.

Bates, C., K. L. Hiett and N. J. Stern, 2004: Relationship of Campylobacter isolated from poultry and from darkling beetles in New Zealand. Avian Dis. 48, 138-147.

Bennett, G., 1993: Cockroaches as carriers of bacteria. Lancet 341, 732.

Berndtson, E., M.-L. Danielsson-Tham and A. Engvall, 1991: Colonization of mice and houseflies with Campylobacter jejuni. In: Ruiz-Palacios, G. M., E. Calva and B. R. Ruiz-Palacios (eds), Proceedings of Fifth International Workshop on Campylobacter Infections. pp. 58-60. National Institute of Nutrition, Mexico, D. F., Puerto Vallerta, Mexico.

Berndtson, E., M. L. Danielsson-Tham and A. Engvall, 1996: Campylobacter incidence on a chicken farm and the spread of Campylobacter during the slaughter process. Int. J. Food Microbiol. 32, 35-47.

Bidawid, S. P., J. F. Edeson, J. Ibrahim and R. M. Matossian, 1978: The role of nonbiting flies in the transmission of enteric pathogens (Salmonella species and Shigella species) in Beirut, Lebanon. Ann. Trop. Med. Parasitol. 72, 117-121.

Brady, J., 1970a: Litter mites and their effects on poultry. Worlds Poultry Science Journal 26, 658-668. 
Brady, J., 1970b: The mites of poultry litter. Observations on the bionomics of common species, with a species list for England and Wales. J. Appl. Ecol. 7, 331348.

Brown, D. J., J. E. Olsen and M. Bisgaard, 1992: Salmonella enterica: infection, cross infection and persistence within the environment of a broiler parent stock unit in Denmark. Zentralbl. Bakteriol. 277, 129-138.

Buriro, S. N., 1983: Relative abundance of different species of bacteria isolated from Argas (persicargas) persicus, Oken. Pakistan Vet. J. 3, 126-128.

Chauve, C., 1998: The poultry red mite Dermanyssus gallinae (De Geer, 1778): current situation and future prospects for control. Vet. Parasitol. 79, 239-245.

Chirico, J., H. Eriksson, O. Fossum and D. Jansson, 2003: The poultry red mite, Dermanyssus gallinae, a potential vector of Erysipelothrix rhusiopathiae causing erysipelas in hens. Med. Vet. Entomol. 17, 232-234.

Cohen, D., M. Green, C. Block, R. Slepon, R. Ambar, S. S. Wasserman and M. M. Levine, 1991: Reduction of transmission of shigellosis by control of houseflies (Musca domestica). Lancet 337, 993-997.

Conway, J. A., 1973: The micro-fauna of Californian-system poultry houses in Britain. Br. Poult. Sci. 14, 213-216.

Craven, S. E., N. J. Stern, J. S. Bailey and N. A. Cox, 2001: Incidence of Clostridium perfringens in broiler chickens and their environment during production and processing. Avian Dis. 45, 887-896.

Crippen, T. L. and C. Sheffield, 2006: External surface disinfection of the lesser mealworm (Coleoptera : Tenebrionidae). J. Med. Entomol. 43, 916-923.

Crowley, L. D. and M. A. Houck, 2002: The immune response of larvae and pupae of Calliphora vicina (Diptera: Calliphoridae), upon administered insult with Escherichia coli. J. Med. Entomol. 39, 931-934.

Curtis, P. E. and F. Boachie, 1982: Survey of the health and husbandry of small poultry flocks in Great Britain. Vet. Rec. 111, 216-219.

Danks, H. V., 2006: Short life cycles in insects and mites. Can. Entomol. 138, 407463.

Davies, R. and M. Breslin, 2003a: Observations on Salmonella contamination of commercial laying farms before and after cleaning and disinfection. Vet. Rec. 152, 283-287.

Davies, R., M. Breslin, J. E. Corry, W. Hudson and V. M. Allen, 2001: Observations on the distribution and control of Salmonella species in two integrated broiler companies. Vet. Rec. 149, 227-232.

Davies, R. H. and M. Breslin, 2003b: Persistence of Salmonella Enteritidis phage type 4 in the environment and arthropod vectors on an empty free-range chicken farm. Environ. Microbiol. 5, 79-84.

Davies, R. H. and C. Wray, 1995: Contribution of the lesser mealworm beetle (Alphitobius diaperinus) to carriage of Salmonella enteritidis in poultry. Vet. Rec. 137, 407-408.

Davila, M., M. Rebollo and G. Tellez, 1996: The importance of the beetle Alphitobius diaperinus in poultry litter as a vector of Salmonella sp. and Escherichia coli in poultry farms in Mexico. Proceedings of 45th Western Poultry Disease Conference. pp. 291-293. Cancun, Mexico.

de Chirinos, N. I. M., A. R. Chirinos, Y. Hinestroza, M. F. Inicarte, M. Manco and A. Melendez, 2001: Prevalence of ectoparasites in domestic fowls (Gallus gallus domesticus) from the San Francisco municipality in Zulia state, Venezuela. Rev. Cient. (Maracaibo) 11, 348-354. 
de las Casas, E., B. S. Pomeroy and P. K. Harein, 1968: Infection and quantitative recovery of Salmonella typhimurium and Escherichia coli from within the lesser mealworm, Alphitobius diaperinus (Panzer). Poult. Sci. 47, 1871-1875.

De Vaney, J. A., 1986: Ectoparasites. Poult. Sci. 65, 649-656.

De Vaney, J. A., J. H. Quisenberry, B. H. Doran and J. W. Bradley, 1980: Dispersal of the northern fowl mite, Ornithonyssus sylviarum (Canestrini and Fanzago), and the chicken body louse, Menacanthus stramineus (Nitzsch), among thirty strains of egg-type hens in a caged laying house. Poult. Sci. 59, 1745-1749.

Despins, J. L., R. C. Axtell, D. V. Rives, J. S. Guy and M. D. Ficken, 1994: Transmission of enteric pathogens of turkeys by darkling beetle larva (Alphitobius diaperinus). J. Appl. Poult. Res. 3, 61-65.

Dulceanu, N., A. Dascalu, V. Clipa and E. Sasu, 1975: Observations on attacks by Cimex lectularius on fowls. Cerc. Agron. Moldova 8, 121-124.

Eddie, B., K. F. Meyer, F. L. Lambrecht and D. P. Furman, 1962: Isolation of Ornithosis bedsoniae from mites collected in turkey quarters and from chicken lice. J. Infect. Dis. 110, 231-237.

Erickson, M. C., M. Islam, C. Sheppard, J. Liao and M. P. Doyle, 2004: Reduction of Escherichia coli O157:H7 and Salmonella enterica serovar Enteritidis in chicken manure by larvae of the black soldier fly. J. Food Prot. 67, 685-690.

Ernst, P. B. and B. D. Gold, 2000: The disease spectrum of Helicobacter pylori: the immunopathogenesis of gastroduodenal ulcer and gastric cancer. Annu. Rev. Microbiol. 54, 615-640.

Farkas, R. and L. Papp, 1989: Species composition and breeding sites of fly communities (Diptera) in caged-layer houses in Hungary. Parasit. Hung. 22, 9398.

Fathpour, H., G. Emtiazi and E. Ghasemi, 2003: Cockroaches as reservoirs and vectors of drug resistant Salmonella spp. Fresen. Environ. Bull. 12, 724-727.

Fernandes, M. A., M. A. S. Santos and C. Lomonaco, 1995: Occurrence of arthropods in accumulated manure in a poultry house. Anais Soc. Ent. Bras. 24, 649-654.

Fiddes, M. D., S. Le Gresley, D. G. Parsons, C. Epe, G. C. Coles and K. A. Stafford, 2005: Prevalence of the poultry red mite (Dermanyssus gallinae) in England. Vet. Rec. 157, 233-235.

Foerster, M., S. Klimpel, H. Mehlhorn, K. Sievert, S. Messler and K. Pfeffer, 2007: Pilot study on synanthropic flies (e.g. Musca, Sarcophaga, Calliphora, Fannia, Lucilia, Stomoxys) as vectors of pathogenic microorganisms. Parasitol. Res. 101, 243-246.

Freeman, J. A., 1979: Infestation of grain and Feeding stuffs. National Agricultural Advisory Service Quarterly Journal 45, 11-19.

Garber, L., M. Smeltzer, P. Fedorka-Cray, S. Ladely and K. Ferris, 2003: Salmonella enterica serotype Enteritidis in table egg layer house environments and in mice in US layer houses and associated risk factors. Avian Dis. 47, 134-142.

Geden, C. J., J. J. Arends, R. C. Axtell, D. R. Barnard, D. M. Gaydon, L. A. Hickle, J. A. Hogsette, W. F. Jones, B. A. Mullens, M. P. J. Nolan, M. P. I. Nolan, J. J. Petersen and D. C. Sheppard, 2001: Poultry. In: Geden, C. J. and J. A. Hogsette (eds), Research and extension needs for integrated pest management for arthropods of veterinary importance: Proceedings of a workshop in Lincoln, Nebraska, April 12-14, 1994, updated October 2001., pp. 2-35. Center for Medical, Agricultural, and Veterinary Entomology USDA-ARS, Gainesville, Florida.

Geden, C. J. and J. G. Stoffolano, Jr., 1988: Dispersion patterns of arthropods associated with poultry manure in enclosed houses in Massachusetts: spatial 
distribution and effects of manure moisture and accumulation time. J. Entomol. Sci. 23, 136-148.

Glukhov, V. F., 1972: The role of ticks in the dissemination of fowl paratyphoid. Veterinariya (Mosc.) 4, 49-50.

Glukhov, V. F., V. G. Novikov and V. A. Kravtsov, 1982: Vectors of Salmonella and Escherichia infections of poultry (Cimex lectularius). Veterinariya (Mosc.) 7, 3739.

Goddard, J., 2006: An annotated list of the ticks (Ixodidae and Argasidae) of Mississippi. J. Vector Ecol. 31, 206-209.

Goodwin, M. A. and W. D. Waltman, 1996: Transmission of Eimeria, viruses, and bacteria to chicks: darkling beetles (Alphitobius diaperinus) as vectors of pathogens. J. Appl. Poult. Res. 5, 51-55.

Gray, J. P., C. W. Maddox, P. C. Tobin, J. D. Gummo and C. W. Pitts, 1999: Reservoir competence of Carcinops pumilio for Salmonella enteritidis (Eubacteriales: Enterobacteriaceae). J. Med. Entomol. 36, 888-891.

Green, D. B., 1982: The fauna and environment of two Lancashire deep-pit poultry houses. Ministry of Agriculture, Fisheries and Food: Poultry 140, 15-32.

Greenberg, B., 1964: Experimental transmission of Salmonella Typhimurium by houseflies to man. Am. J. Hyg. 80, 149-156.

Greenberg, B. and M. Klowden, 1972: Enteric bacterial interactions in insects. Am. J. Clin. Nutr. 25, 1459-1466.

Greenberg, B., J. A. Kowalski and M. J. Klowden, 1970: Factors affecting the transmission of Salmonella by flies: natural resistance to colonization and bacterial interference. Infect. Immun. 2, 800-809.

Gregory, E., H. Barnhart, D. W. Dreesen, N. J. Stern and J. L. Corn, 1997: Epidemiological study of Campylobacter spp. in broilers: Source, time of colonization, and prevalence. Avian Dis. 41, 890-898.

Guard-Petter, J., 2001: The chicken, the egg and Salmonella enteritidis. Environ. Microbiol. 3, 421-430.

Gustafson, C. R., A. A. Bickford, G. L. Cooper and B. R. Charlton, 1997: Sticktight fleas associated with fowl pox in a backyard chicken flock in California. Avian Dis. 41, 1006-1009.

Gyurov, B., 1983: Role of Argas persicus in the epidemiology of fowl typhoid. Vet. Sbirka 81, 22-24.

Hald, B., A. Olsen and M. Madsen, 1998: Typhaea stercorea (Coleoptera : Mycetophagidae), a carrier of Salmonella enterica serovar Infantis in a Danish broiler house. J. Econ. Entomol. 91, 660-664.

Hald, B., H. Skovgard, D. D. Bang, K. Pedersen, J. Dybdahl, J. B. Jespersen and M. Madsen, 2004: Flies and Campylobacter infection of broiler flocks. Emerg. Infect. Dis. 10, 1490-1492.

Hald, B., H. M. Sommer and H. Skovgard, 2007: Use of fly screens to reduce Campylobacter spp, introduction in broiler houses. Emerg. Infect. Dis. 13, 19511953.

Hancock, D. D., T. E. Besser, D. H. Rice, E. D. Ebel, D. E. Herriott and L. V. Carpenter, 1998: Multiple sources of Escherichia coli O157 in feedlots and dairy farms in the northwestern USA. Prev. Vet. Med. 35, 11-19.

Harrington, L. C. and R. C. Axtell, 1994: Comparisons of sampling methods and seasonal abundance of Drosophila repleta in caged-layer poultry houses. Med. Vet. Entomol. 8, 331-339. 
Heuvelink, A. E., F. van den Biggelaar, J. T. M. Zwartkruis-Nahuis, R. G. Herbes, R. Huyben, N. Nagelkerke, W. J. G. Melchers, L. A. H. Monnens and E. de Boer, 1998: Occurrence of verocytotoxin-producing Escherichia coli O157 on Dutch dairy farms. J. Clin. Microbiol. 36, 3480-3487.

Hinkle, N. C. and L. A. Hickle, 1999: California caged layer pest management evaluation. J. Appl. Poult. Res. 8, 327-338.

Hogsette, J. A. and R. D. Jacobs, 2003: The black dump fly: A larval predator of house flies (document PS25). Institute of Food and Agricultural Sciences, University of Florida (UF/IFAS), Florida, USA.

Hogue, A., P. White, J. Guard-Petter, W. Schlosser, R. Gast, E. Ebel, J. Farrar, T. Gomez, J. Madden, M. Madison, A. M. McNamara, R. Morales, D. Parham, P. Sparling, W. Sutherlin and D. Swerdlow, 1997: Epidemiology and control of eggassociated Salmonella enteritidis in the United States of America. Rev. Sci. Tech. $16,542-553$.

Holt, P. S., C. J. Geden, R. W. Moore and R. K. Gast, 2007: Isolation of Salmonella enterica serovar Enteritidis from houseflies (Musca domestica) found in rooms containing Salmonella serovar Enteritidis-challenged hens. Appl. Environ. Microbiol. 73, 6030-6035.

Hughes, A. M., 1976: The mites of stored food and houses. Technical bulletin No. 9, 2nd edition; Ministry of Agriculture, Fisheries and Food. Her Majesty's Stationery Office, London, UK.

Jacobs-Reitsma, W. F., A. W. van de Giessen, N. M. Bolder and R. W. A. Mulder, 1995: Epidemiology of Campylobacter spp at 2 Dutch broiler farms. Epidemiol. Infect. 114, 413-421.

Jones, F. T., R. C. Axtell, D. V. Rives, S. E. Scheideler, F. R. Tarver, R. I. Walker and M. J. Wineland, 1992: A survey of Campylobacter jejuni contamination in modern broiler production and processing systems. J. Food Prot. 54, 259-262.

Julseth, R. M., J. K. Felix, W. E. Burkholder and R. H. Deibel, 1969: Experimental transmission of Enterobacteriaceae by insects. I. Fate of Salmonella fed to the hide beetle Dermestes maculatus and a novel method for mounting insects. Appl. Microbiol. 17, 710-713.

Kaufman, P. E., C. Reasor, K. D. Murray, J. K. Waldron and D. A. Rutz, 2005: Evaluation of a barrier to inhibit lesser mealworm (Coleoptera: Tenebrionidae) and Dermestidae movement in high-rise, caged-layer poultry facilities. J. Econ. Entomol. 98, 1744-1749.

Kennedy, R. and M. Connell, 1969: Mites. In: Infestation control: report of the Infestation Control Laboratory 1965-67. Her Majesty's Stationary Office, London, UK.

Khan, M. N., L. A. Khan, S. Mahmood and A. Qudoos, 2001: Argas persicus infestation: prevalence and economic significance in poultry. Pakistan Journal of Agricultural Sciences 38, 32-34.

Kinde, H., D. M. Castellan, D. Kerr, J. Campbell, R. Breitmeyer and A. Ardans, 2005: Longitudinal monitoring of two commercial layer flocks and their environments for Salmonella enterica serovar Enteritidis and other salmonellae. Avian Dis. 49, 189-194.

Klowden, M. J. and B. Greenberg, 1976: Salmonella in the American cockroach: evaluation of vector potential through dosed feeding experiments. J. Hyg. (Lond). 77, 105-111.

Klowden, M. J. and B. Greenberg, 1977: Effects of antibiotics on the survival of Salmonella in the American cockroach. J. Hyg. (Lond). 79, 339-345. 
Kobayashi, M., T. Sasaki, N. Saito, K. Tamura, K. Suzuki, H. Watanabe and N. Agui, 1999: Houseflies: not simple mechanical vectors of enterohemorrhagic Escherichia coli O157:H7. Am. J. Trop. Med. Hyg. 61, 625-629.

Kopanic, R. J., Jr., B. W. Sheldon and C. G. Wright, 1994: Cockroaches as vectors of Salmonella: laboratory and field trials. J. Food Prot. 57, 125-132.

Letellier, A., S. Messier, J. Pare, J. Menard and S. Quessy, 1999: Distribution of Salmonella in swine herds in Quebec. Vet. Microbiol. 67, 299-306.

Liebana, E., L. Garcia-Migura, C. Clouting, F. A. Clifton-Hadley, M. Breslin and R. H. Davies, 2003: Molecular fingerprinting evidence of the contribution of wildlife vectors in the maintenance of Salmonella Enteritidis infection in layer farms. $J$. Appl. Microbiol. 94, 1024-1029.

Lockley, R. M., 1954: The European rabbit-flea, Spilopsyllus cuniculi as a vector of myxomatosis in Britain. Vet. Rec. 66, 434-435.

Lonc, E. and J. Zlotorzycka, 1984: Connections between poultry biting lice and microflora. Angew. Parasitol. 25, 43-49.

Longbottom, D. and L. J. Coulter, 2003: Animal chlamydioses and zoonotic implications. J. Comp. Pathol. 128, 217-244.

Matsuo, T., Y. Okoda, B. Badgar, N. Inoue, X. N. Xuan, D. Taylor and K. Fujisaki, 2004: Fate of GFP-expressing Escherichia coli in the midgut and response to ingestion in a tick, Ornithodoros moubata (Acari : Argasidae). Exp. Parasitol. 108, 67-73.

McAllister, J. C., C. D. Steelman, J. K. Skeeles, L. A. Newberry and E. E. Gbur, 1996: Reservoir competence of Alphitobius diaperinus (Coleoptera: Tenebrionidae) for Escherichia coli (Eubacteriales: Enterobacteriaceae). J. Med. Entomol. 33, 983-987.

Mian, L. S., H. Maag and J. V. Tacal, 2002: Isolation of Salmonella from muscoid flies at commercial animal establishments in San Bernardino County, California. $J$. Vector Ecol. 27, 82-85.

Monov, M. and E. Topalski, 1980: Distribution and seasonal dynamics of bed-bugs in poultry farms. Vet. Sbirka 78, 21-22.

Montasser, A. A., 2005: Gram-negative bacteria from the camel tick Hyalomma dromedarii (Ixodidae) and the chicken tick Argas persicus (Argasidae) and their antibiotic sensitivities. J. Egypt. Soc. Parasitol. 35, 95-106.

Monteiro, M. R. and A. P. do Prado, 2006: Synanthropic flies (Diptera: Cyclorrapha) and their microhymenoptera parasitoids (Insecta: Hymenoptera) at Monte Mor poultry production system, São Paulo, Brazil. Rev. Bras. Parasitol. Vet. 15, 49-57.

Moore, J. E., D. Corcoran, J. S. G. Dooley, S. Fanning, B. Lucey, M. Matsuda, D. A. McDowell, F. Megraud, B. C. Millar, R. O'Mahony, L. O'Riordan, M. O'Rourke, J. R. Rao, P. J. Rooney, A. Sails and P. Whyte, 2005: Campylobacter. Vet. Res. 36, 351-382.

Mramba, F., A. B. Broce and L. Zurek, 2007: Vector competence of stable flies, Stomoxys calcitrans L. (Diptera : Muscidae), for Enterobacter sakazakii. J. Vector Ecol. 32, 134-139.

Mumcuoglu, K. Y., C. Banet-Noach, M. Malkinson, U. Shalom and R. Galun, 2005: Argasid ticks as possible vectors of West Nile virus in Israel. Vector Borne Zoonotic Dis. 5, 65-71.

Nataro, J. P. and J. B. Kaper, 1998: Diarrheagenic Escherichia coli. Clin. Microbiol. Rev. 11, 142-201.

Nayduch, D., G. P. Noblet and F. J. Stutzenberger, 2002: Vector potential of houseflies for the bacterium Aeromonas caviae. Med. Vet. Entomol. 16, 193-198. 
Nazni, W. A., B. Seleena, H. L. Lee, J. Jeffery, T. A. R. T Rogayah and M. A. Sofian, 2005: Bacteria fauna from the house fly, Musca domestica (L.). Trop. Biomed. 22, 225-231.

Nelson, W. and B. Harris, 2006: Flies, fingers, fomites, and food. Campylobacteriosis in New Zealand: food-associated rather than food-borne. N. Z. Med. J. 119, U2128.

Nolan, M. P. I. and J. B. Kissam, 1987: Nuisance potential of a dump fly, Ophyra aenescens (Diptera: Muscidae), breeding at poultry farms. Environ. Entomol. 16, 828-831.

Olsen, A. R. and T. S. Hammack, 2000: Isolation of Salmonella spp. from the housefly, Musca domestica L., and the dump fly, Hydrotaea aenescens (Wiedemann) (Diptera : Muscidae), at caged-layer houses. J. Food Prot. 63, 958960 .

Ostrolenk, M. and H. Welch, 1942: The house fly as a vector of food poisoning organisms in food producing establishments. Am. J. Public Health 32, 487-494.

Oyoun, L. M. I., K. M. El-Kammah, M. H. Madbouly and S. M. Habeeb, 1990: Ecological studies on poultry ticks and life cycle study of Argas (Argas) hermanni (Audouin, 1827). Bulletin de la Societe Entomologique d'Egypte 69, 287-294.

Palmer, S., S. Parry, D. Perry, R. Smith, M. Evans, L. Nehaul, R. Roberts, M. Walapu and D. Wright, 2000: The role of outbreaks in developing food safety policy: population based surveillance of Salmonella outbreaks in Wales 1986-98. Epidemiol. Infect. 125, 467-472.

Pavlovic, I. and D. Nesic, 1991: Parasitic fauna of poultry industry in the Republic of Serbia in 1989. Veterinarski Glasnik 45, 245-247.

Pfeiffer, D. G. and R. C. Axtell, 1980: Coleoptera of poultry manure in caged-layer houses in North Carolina. Environ. Entomol. 9, 21-28.

Proctor, H. and I. Owens, 2000: Mites and birds: diversity, parasitism and coevolution. Trends Ecol. Evol. 15, 358-364.

Rahn, K., S. A. Renwick, R. P. Johnson, J. B. Wilson, R. C. Clarke, D. Alves, S. McEwen, H. Lior and J. Spika, 1997: Persistence of Escherichia coli O157:H7 in dairy cattle and the dairy farm environment. Epidemiol. Infect. 119, 251-259.

Reboli, A. C. and W. E. Farrar, 1989: Erysipelothrix rhusiopathiae - an occupational pathogen. Clin. Microbiol. Rev. 2, 354-359.

Refregier-Petton, J., N. Rose, M. Denis and G. Salvat, 2001: Risk factors for Campylobacter spp. contamination in French broiler-chicken flocks at the end of the rearing period. Prev. Vet. Med. 50, 89-100.

Rochon, K., T. J. Lysyk and L. B. Selinger, 2005: Retention of Escherichia coli by house fly and stable fly (Diptera: Muscidae) during pupal metamorphosis and eclosion. J. Med. Entomol. 42, 397-403.

Rood, J. I. and S. T. Cole, 1991: Molecular genetics and pathogenesis of Clostridium perfringens. Microbiol. Rev. 55, 621-648.

Rosef, O. and G. Kapperud, 1983: House flies (Musca domestica) as possible vectors of Campylobacter fetus subsp. jejuni. Appl. Environ. Microbiol. 45, 381-383.

Rueda, L. M. and R. C. Axtell, 1997: Arthropods in litter of poultry (broiler chicken and turkey) houses. J. Agric. Entomol. 14, 81-91.

Ruff, M. D., 1999: Important parasites in poultry production systems. Vet. Parasitol. 84, 337-347.

Santos, B., 2000: Transmission of Escherichia coli by the American dust mite, Dermatophagoides farinae (Acari: Pyroglyphidae). International Journal of Acarology 26, 243-245. 
Sasaki, T., M. Kobayashi and N. Agui, 2000: Epidemiological potential of excretion and regurgitation by Musca domestica (Diptera: Muscidae) in the dissemination of Escherichia coli O157: H7 to food. J. Med. Entomol. 37, 945-949.

Schmidt, J. R. and M. I. Said, 1964: Isolation of West Nile virus from the African bird argasid, Argas reflexus Hermanni, in Egypt. J. Med. Entomol. 39, 83-86.

Shah, A. H., M. N. Khan, Z. Iqbal, M. S. Sajid and M. S. Akhtar, 2006: Some epidemiological aspects and vector role of tick infestation on layers in the Faisalabad district (Pakistan). Worlds Poult. Sci. J. 62, 145-157.

Shane, S. M., M. S. Montrose and K. S. Harrington, 1985: Transmission of Campylobacter jejuni by the housefly (Musca domestica). Avian Dis. 29, 384-391.

Shere, J. A., K. J. Bartlett and C. W. Kaspar, 1998: Longitudinal study of Escherichia coli $\mathrm{O} 157$ : $\mathrm{H} 7$ dissemination on four dairy farms in Wisconsin. Appl. Environ. Microbiol. 64, 1390-1399.

Shineng, L. and F. J. Stutzenberger, 2000: The housefly (Musca domestica) as a possible vector for Helicobacter pylori at agricultural sites. Int. J. Environ. Health Res. 10, 141-152.

Skov, M. N., O. Angen, M. Chriel, J. E. Olsen and M. Bisgaard, 1999: Risk factors associated with Salmonella enterica serovar typhimurium infection in Danish broiler flocks. Poult. Sci. 78, 848-854.

Skov, M. N., J. J. Madsen, C. Rahbek, J. Lodal, J. B. Jespersen, J. C. Jørgensen, H. H. Dietz, M. Chriél and D. L. Baggesen, 2008: Interactions between Salmonella (Salmonella enterica) in wildlife and domestic animals in Denmark. J. Appl. Microbiol. In press.

Skov, M. N., A. G. Spencer, B. Hald, L. Petersen, B. Nauerby, B. Carstensen and M. Madsen, 2004: The role of litter beetles as potential reservoir for Salmonella enterica and thermophilic Campylobacter spp. between broiler flocks. Avian Dis. 48, 9-18.

Srivastava, S. C., M. H. Khan and R. Moin, 1981: Note on the biology of poultry tick, Argas persicus (Oken) (Acarina, Argasidae). Indian J. Anim. Sci. 51, 387-389.

Stefanov, V., I. Matev and I. Balimezov, 1975: The role of ticks of the species Argas persicus Oken, 1818, in the epizootiology of pullorum disease. Vet. Med. Nauki 12, 45-50.

Stern, N. J., M. A. Myszewski, H. M. Barnhart and D. W. Dreesen, 1997: Flagellin A gene restriction fragment length polymorphism patterns of Campylobacter spp. isolates from broiler production sources. Avian Dis. 41, 899-905.

Strother, K. O., C. D. Steelman and E. E. Gbur, 2005: Reservoir competence of lesser mealworm (Coleoptera : Tenebrionidae) for Campylobacter jejuni (Campylobacterales : Campylobacteraceae). J. Med. Entomol. 42, 42-47.

Sulaiman, S., M. Z. Othman and A. H. Aziz, 2000: Isolations of enteric pathogens from synanthropic flies trapped in downtown Kuala Lumpur. J. Vector Ecol. 25, 90-93.

Szalanski, A. L., C. B. Owens, T. McKay and C. D. Steelman, 2004: Detection of Campylobacter and Escherichia coli O157:H7 from filth flies by polymerase chain reaction. Med. Vet. Entomol. 18, 241-246.

Tatfeng, Y. M., M. U. Usuanlele, A. Orukpe, A. K. Digban, M. Okodua, F. Oviasogie and A. A. Turay, 2005: Mechanical transmission of pathogenic organisms: the role of cockroaches. J. Vector Borne Dis. 42, 129-134.

Tellam, R. L., G. Wijffels and P. Willadsen, 1999: Peritrophic matrix proteins. Insect Biochem. Mol. Biol. 29, 87-101. 
Templeton, J. M., A. J. De Jong, P. J. Blackall and J. K. Miflin, 2006: Survival of Campylobacter spp. in darkling beetles (Alphitobius diaperinus) and their larvae in Australia. Appl. Environ. Microbiol. 72, 7909-7911.

Thind, B. B., 2000: Determination of low levels of mite and insect contaminants in food and feedstuffs by a modified flotation method. J. AOAC Int. 83, 113-119.

Thind, B. B. and H. L. Ford, 2007: Assessment of susceptibility of the poultry red mite Dermanyssus gallinae (Acari : Dermanyssidae) to some acaricides using an adapted filter paper based bioassay. Vet. Parasitol. 144, 344-348.

Turchetto, M. and S. Vanin, 2004: Forensic entomology and climatic change. Forensic Sci. Int. 146, S207-S209.

Turner, E. C., Jr., 1986: Structural and litter pests. Poult. Sci. 65, 644-648.

Urquhart, G. M., J. Armour, J. L. Duncan, A. M. Dunn and F. W. Jennings, 1987a: Class Haemosporidia. In: Veterinary Parasitology, p. 242. Longman, Bath (UK).

Urquhart, G. M., J. Armour, J. L. Duncan, A. M. Dunn and F. W. Jennings, 1987b: Family Argasidae. In: Veterinary Parasitology, pp. 182-183. Longman, Bath (UK).

Urquhart, G. M., J. Armour, J. L. Duncan, A. M. Dunn and F. W. Jennings, 1987c: Ornithonyssus. In: Veterinary Parasitology, p. 198. Longman, Bath (UK).

Valiente Moro, C., C. Chauve and L. Zenner, 2005: Vectorial role of some dermanyssoid mites (Acari, Mesostigmata, Dermanyssoidea). Parasite 12, 99-109.

Valiente Moro, C., C. Chauve and L. Zenner, 2007a: Experimental infection of Salmonella Enteritidis by the poultry red mite, Dermanyssus gallinae. Vet. Parasitol. 146, 329-336.

Valiente Moro, C., S. Desloire, C. Chauve and L. Zenner, 2007b: Detection of Salmonella sp. in Dermanyssus gallinae using an FTA ${ }^{\circledR}$ filter-based polymerase chain reaction. Med. Vet. Entomol. 21, 148-152.

Valiente Moro, C., P. Fravalo, M. Amelot, C. Chauve, L. Zenner and G. Salvat, 2007c: Colonization and organ invasion in chicks experimentally infected with Dermanyssus gallinae contaminated by Salmonella Enteritidis. Avian Pathol. 36, $307-311$.

van Immerseel, F., 2004: Clostridium perfringens in poultry: an emerging threat for animal and public health. Avian Pathol. 33, 537-549.

Vanselow, B. A., M. A. Hornitzky, K. H. Walker, G. J. Eamens, G. D. Bailey, P. A. Gill, K. Coates, B. Corney, J. P. Cronin and S. Renilson, 2007: Salmonella and onfarm risk factors in healthy slaughter-age cattle and sheep in eastern Australia. Aust. Vet. J. 85, 498-502.

Vashchenok, V.S., 1980: Some reproductive peculiarities of microbes in fleas Xenopsylla cheopis (Siphonaptera) during parenteral infection. Parazitologiya (Leningrad) 14, 477-481.

Velge, P., A. Cloeckaert and P. Barrow, 2005: Emergence of Salmonella epidemics: the problems related to Salmonella enterica serotype Enteritidis and multiple antibiotic resistance in other major serotypes. Vet. Res. 36, 267-288.

Wales, A., M. Breslin and R. Davies, 2006a: Semiquantitative assessment of the distribution of Salmonella in the environment of caged layer flocks. J. Appl. Microbiol. 101, 309-318.

Wales, A. D., R. H. Davies and M. Breslin, 2006b: Assessment of cleaning and disinfection in Salmonella-contaminated poultry houses using qualitative and semiquantitative culture techniques. Vet. Microbiol. 116, 283-293.

Wilkin, D. R. and B. B. Thind, 1984: Stored product mites detection and loss assessment in animal feed. In: Mills, R. B., V. F. Wright, J. R. Pedersen, W. H. McGaughey, R. W. Beeman, K. J. Kramer, R. D. Speirs and C. L. Storey (eds), 
Proceedings of 3rd International working conference on stored-product entomology, 23-28 October 1983. pp. 608-620. International Working Conferences on Stored-Product Protection, Manhattan, Kansas, USA.

Williams, G. C., 1960: The infestation of compound feedingstuffs derived from provinder mills. Technical Circular, Infestation Control Laboratory, UK Ministry of Agriculture, Fisheries and Food, vol 38 (7).

Winpisinger, K. A., A. K. Ferketich, R. L. Berry and M. L. Moeschberger, 2005: Spread of Musca domestica (Diptera: muscidae), from two caged layer facilities to neighboring residences in rural Ohio. J. Med. Entomol. 42, 732-738.

Wittenberg, R., M. Kenis, T. Blick, A. Hänggi, A. Gassmann and E. Weber, 2005: An inventory of alien species and their threat to biodiversity and economy in Switzerland. CABI Bioscience Switzerland Centre report to The Swiss Agency for Environment Forests and Landscape. Delémont, Switzerland.

Zeman, P., V. Stika, B. Skalka, M. Bartik, F. Dusbabek and M. Lavickova, 1982: Potential role of Dermanyssus gallinae in the circulation of the agent of pullurosis typhus in hens. Folia Parasitol. 29, 371-374.

Zurek, L., S. S. Denning, C. Schal and D. W. Watson, 2001: Vector competence of Musca domestica (Diptera: Muscidae) for Yersinia pseudotuberculosis. J. Med. Entomol. 38, 333-335.

Zurek, L., C. Schal and D. W. Watson, 2000: Diversity and contribution of the intestinal bacterial community to the development of Musca domestica (Diptera: Muscidae) larvae. J. Med. Entomol. 37, 924-928. 